\title{
Evaluation of antimicrobial activity and ethnobotanical study of Cannabis sativa \\ L.
}

\author{
Musfirah Anjum*, Zel-E-Arooj, Sidra Azam, Pakeeza Rehman and \\ Jamila Khadim
}

Department of Botany (Bhimber Campus), Mirpur University of Science \& Technology (MUST), Mirpur-10250

(AJK)-Pakistan

*Corresponding author's email: Musfirah.anjum@yahoo.com

Citation

Musfirah Anjum, Zel-E-Arooj, Sidra Azam, Pakeeza Rehman and Jamila Khadim. Evaluation of antimicrobial activity and ethnobotanical study of Cannabis sativa L. Pure and Applied Biology. Vol. 7, Issue 2, pp706-713. http://dx.doi.org/10.19045/bspab.2018.70088

Received: 20/03/2018 Revised: 06/06/2018

Accepted: $21 / 06 / 2018$

Online First: 25/06/2018

\section{Abstract}

Plants are a great source of antibacterial components. Many plant extracts are being used in daily life to fight fungal and bacterial infections. In the present study in vitro, test confirmed the activity of antimicrobial of Cannabis sativa L. extracts against different bacterial and fungal strains. Antimicrobial efficiency of $C$. sativa a therapeutic plant (extracts of leaf) was screened using acetone, chloroform, water and ethanol, as solvents and tested against three Bacteria: E. coli, Staphylococcus aureus and P. aeruginosa, Fungi: A.niger and Fusarium spp. by disk diffusion and agar well diffusion method. All the plant extracts exhibited significant effects on antimicrobes, but the ethanolic extract and acetone extracts of $C$. sativa exposed highest zone of inhibition against most of the microorganisms that are under study. The minimum zone of inhibition was determined in distilled water and chloroform extract of $C$. sativaexhibited minimum activity of antimicrobial against some the tested strains. To find out the ethno botanical uses of $C$. sativa a survey from the rural people of study area (Bhimber Rajani) was carried out, by interviewing the local inhabitants through a questionnaire. It was noticed that it is used assedative, narcotic, intoxicant and analgesic. As a green manure leaves are used. Hashish or Charas is also prepared from it. The powder is used for bronchitis, cough and chest problems.

Keywords: Antibacterial activity; Ethnobotany; Medicinal plants

\section{Introduction}

The utilization of plants for treating diseases, to flavor and conserve food is as ancient as the human history. According to WHO, it was claimed that indigenous plants have been employed since long time ago and according to consideration it has been concluded that in the region of Africa, $80 \%$ inhabitants utilized therapeutic plants via extraction for curing principle [1]. Above than 50,000 herbal plants has employed in pharmaceuticals by The Food Agriculture Organization. Plant products have potential to control microbial growth in diverse situations and to treat many diseases [2].

For the human health drug resistance of microorganisms is a big risk. To reduce this problem, herbal medicines were used as 
alternative potential treatment. For treating many diseases plants used traditionally and no sign of drug resistance has been reported till now.In our medical exercise hundreds of plants are used just like Cannabis sativa L. is a plant that has chemical elements and effects. In the past Cannabis is the great controversial plant [3]. Now a days $C$. sativa would be exposed,rising in some portions of the world, its nature would be healed; that plant has the potential to cure the disease from headaches to cancer to nervous disorders.

The objective of this work is to evaluate the antimicrobial activity of the extracts of Cannabis sativa grown in Bhimber, AJK, Pakistan against standard bacteria and the fungi.

\section{Materials and methods \\ Plant material}

Leaves of $C$. sativa were collected from Bhimber AJK. The leaves were shadow dried and crushed into powder using an electrical mixer. For further use powder was kept in air tight containers.

\section{Test organisms}

Clinical isolates of three bacteria ( $S$. aureus, E. coli, $P$. aeruginosa) fungal strains (A.niger and Fusarium spp.) were selected on their pharmacological and clinical importance. The fungal and bacterial stock cultures were incubated for 37 hours at $24^{\circ} \mathrm{C}$ on potato dextrose agar (PDA) and nutrient agar medium respectively, next kept in refrigerator at $4^{\circ} \mathrm{C}$.

\section{Preparation of plant extracts}

Leaf extraction of $C$. sativa was completed with acetone, chloroform, $60 \%$ Ethanol and distilled water. For preparing extracts, $10 \mathrm{~g}$ of dry leaf powder of $C$. sativa was taken and mixed with $100 \mathrm{ml}$ of each solvent. The mixtures of acetone and chloroform were kept for $48 \mathrm{~h}$ and mixtures of ethanol and water were kept for 5 days, to ensure maximum metabolite extraction. The filtered extracts were stored at $4^{\circ} \mathrm{C}[4]$.

\section{Antibacterial screening Paper disc diffusion method}

Nutrient Agar plates and potato dextrose agar (PDA) were prepared and by the spread plate method experimental microorganisms were inoculated. Previously prepared agar plates used for the antimicrobial activity. On that plates filter paper discs about $6 \mathrm{~mm}$ in diameter were soaked with the plant extract was used. The agar plates were then incubated at $37^{\circ} \mathrm{C}$. After the incubation diameters of the zone of inhibition were measured in millimeters. All these experiments performed at least three times. Average values ( \pm standard deviation) are reported in this study. Standard discs of Ampiciline $(2 \mu \mathrm{g})$ served as positive controls for antimicrobial activity [5].

Agar-well diffusion method

Nutrient Agar plates and potato dextrose agar (PDA) were prepared and the assessment microorganisms were inoculated by the spread plate method. Petri plates containing $20 \mathrm{ml}$ nutrient agar and potato dextrose agar (PDA) were seeded with $24 \mathrm{hr}$ culture of bacterial and fungal strains respectively. On these plates, wells $(10 \mathrm{~mm}$ diameter and about $2 \mathrm{~cm}$ a part) were dug with the help of a sterile borer. Each plate had six wells at equal distance. For each pathogen as well as for plant sample, separate plates were prepared. By the $20 \mu 1$ plant extracts were filled the wells (namely distilled water, methanol, acetone and chloroform extracts). The plates were then incubated at $37^{\circ} \mathrm{C}$ for $18-24 \mathrm{~h}$ for bacterial pathogens and $28^{\circ} \mathrm{C}$ for 48 hours fungal pathogens. Antibacterial or antifungal activity of each extract was expressed in terms of zone of inhibition (diameter in $\mathrm{mm}$ ) formed around the well. Ampicillin disc and distilled water were used as a positive control [6].

Ethnomedicinal/ Folklore therapeutic uses of the plant from study area methodology used for data collection 
There is a broad range of potential therapeutic applications of $C$. sativa, due to which it is extensively used for various purposes. The data are gathered by using the questionnaire method from the study area. In order to extract maximum knowledge from people a survey plan was designed and causal interview were taken from the inhabitants. The field survey was conducted during the year 2014 in the months of June, July, August and September. Several visits were made to Tehsil Bhimber of District Bhimber. This field data was first collected and then documented from the selective areas of district Bhimber. During the field trips the information was collected by questionnare method. In this way a maximum information was collected about the folklore uses of Cannabis sativa.

\section{Statistical analysis}

All the data that was collected was analyzed by applying statistics on data. Simple arithmetic means of the different extracts and standard error was used to find out the antimicrobial activity of C.sativa. Data of the questionnaire was analyzed using DMR. DMR was used to find out the used citation of given plant species based on the data collected from the respondents. The values (average scores) were summed up and ranked.

\section{Results and discussion}

The results portrayed that the leaves of Cannabis sativa have antibacterial and antifungal activity on selected pathogens. Effectiveness of different extracts is determined by the size of the control organism growth inhibition zone around the well (diameter of zone in $\mathrm{mm}$ ).

Table 1 and figure 1 showed that the wider zone of inhibition was shown by the acetone extract, i.e., $24.6 \mathrm{~mm}$ while the value deceases to $17.6 \mathrm{~mm}$ of aqueous extract when tested against the bacteria. The result showed that there is a need to used a broad range of extractive solvents in the extractions of possibly phytochemicals from medicinal plants.

As compared to disc method wider zones of inhibition obtainted by agar well diffusion assay. The zone of inhibition was $29 \mathrm{~mm}$ for the extract of ethanol of plant against Escherichia coli. For the paper disc assay agar diffusion assay was used against 19.3 mm. According to Omenka and Osuaba [7], for the enhancing contact with the organism agar well diffusion assay permits well diffusion of the extracts into the medium. As a barrier paper discs play a role between the organism and extract, through the discs into the medium avoiding complete dispersion of active components absorbed and also responsible for the experimental variances, shown in (Table $1 \&$, Figure $1 \& 2$ ).

Results represented in (Table 3 \& Figure 3 ) showed that best solvent of aqueous and ethanolic extracts for extracting antifungal elements from this plant compared to water and chloroform. The extensive zone of inhibition $(24.3 \mathrm{~mm})$ for aqueous and $23 \mathrm{~mm}$ for ethanolic extract, was demonstrated while the value dropped to $18.3 \mathrm{~mm}$ for chloroform extract, when tested against the fungi.

The larger zone of inhibition was $29.6 \mathrm{~mm}$ for the aqueous extracts of $C$. sativa against Aspergillus niger when agar diffusion assay was used, it's the maximum value and the smallest zone of inhibition was for $12.6 \mathrm{~mm}$ for aqueous extract, shown in (Table $4 \&$ Figure 4). 
Table 1. Measurement of antibacterial activity (zone of inhibition, mm) of Cannabis sativa Leaf extracts using paper disc method

\begin{tabular}{|l|l|l|l|l|l|}
\hline $\begin{array}{l}\text { Experimented } \\
\text { Organisms }\end{array}$ & $\begin{array}{l}\text { Acetone } \\
\text { extract }\end{array}$ & $\begin{array}{l}\text { Chloroform } \\
\text { extract }\end{array}$ & $\begin{array}{l}\text { Ethanol } \\
\text { extract }\end{array}$ & $\begin{array}{l}\text { Aqueous } \\
\text { extract }\end{array}$ & Ampicillin \\
\hline Escherichia coli & $24.66 \pm 1.52$ & $23 \pm 2$ & $19.33 \pm 1.15$ & $20.3 \pm 0.57$ & $17.3 \pm 0.57$ \\
\hline Staphylococcus aureus & $19.6 \pm 2.08$ & $18.6 \pm 2.08$ & $18.6 \pm 3.05$ & $24.6 \pm 4.16$ & $18 \pm 1$ \\
\hline Pseudomonas aeruginosa & $19 \pm 2.6$ & $22.3 \pm 1.52$ & $20 \pm 1$ & $17.6 \pm 1.52$ & $19.6 \pm 2.5$ \\
\hline
\end{tabular}

Table 2. Measurement of antibacterial activity (zone of inhibition, $\mathbf{m m}$ ) of leaf extracts of Cannabis sativa using agar well diffusion method

\begin{tabular}{|l|l|l|l|l|l|}
\hline Test Organisms & $\begin{array}{l}\text { Acetone } \\
\text { extract }\end{array}$ & $\begin{array}{l}\text { Chloroform } \\
\text { extract }\end{array}$ & $\begin{array}{l}\text { Ethanol } \\
\text { extract }\end{array}$ & $\begin{array}{l}\text { Aqueous } \\
\text { extract }\end{array}$ & Ampicillin \\
\hline Escherichia coli & $18 \pm 1$ & $19.6 \pm 2.08$ & $29 \pm 1$ & $21.6 \pm 1.52$ & $22.6 \pm 2.08$ \\
\hline Staphylococcus aureus & $19.6 \pm 2.5$ & $19.3 \pm 2.08$ & $23.3 \pm 2.08$ & $26.3 \pm 3.05$ & $19.6 \pm 1.52$ \\
\hline Pseudomonas aeruginosa & $18.6 \pm 2.8$ & $18 \pm 1$ & $22 \pm 1$ & $25 \pm 2.6$ & $19 \pm 1.7$ \\
\hline
\end{tabular}

Table 3. Measurement of antifungal activity (zone of inhibition, $\mathbf{m m}$ ) of leaf extracts of Cannabis sativa using paper disc method

\begin{tabular}{|l|l|l|l|l|l|}
\hline Test Organisms & $\begin{array}{l}\text { Acetone } \\
\text { extract }\end{array}$ & $\begin{array}{l}\text { Chloroform } \\
\text { extract }\end{array}$ & $\begin{array}{l}\text { Ethanol } \\
\text { extract }\end{array}$ & $\begin{array}{l}\text { Aqueous } \\
\text { extract }\end{array}$ & $\begin{array}{l}\text { Distilled } \\
\text { water as } \\
\text { control }\end{array}$ \\
\hline Aspergillus niger & $21.3 \pm 2$ & $20.6 \pm 1.5$ & $23 \pm 2$ & $21 \pm 2.6$ & 00 \\
\hline Fusarium spp. & $20 \pm 2.64$ & $18.3 \pm 1.52$ & $21.3 \pm 3.21$ & $24.3 \pm 3.51$ & 00 \\
\hline
\end{tabular}

Table 4. Measurement of antifungal activity (zone of inhibition, $\mathrm{mm}$ ) of leaf extracts of Cannabis sativa using agar well diffusion method

\begin{tabular}{|l|l|l|l|l|l|}
\hline Test Organisms & $\begin{array}{l}\text { Acetone } \\
\text { extract }\end{array}$ & $\begin{array}{l}\text { chloroform } \\
\text { extract }\end{array}$ & $\begin{array}{l}\text { Ethanol } \\
\text { extract }\end{array}$ & $\begin{array}{l}\text { Aqueous } \\
\text { extract }\end{array}$ & $\begin{array}{l}\text { Distilled } \\
\text { water as } \\
\text { control }\end{array}$ \\
\hline Aspergillus niger & $19.3 \pm 1.15$ & $19.6 \pm 2.08$ & $18 \pm 1$ & $19 \pm 1$ & 00 \\
\hline Fusarium spp. & $13.6 \pm 1.52$ & $16.6 \pm 0.57$ & $13 \pm 1$ & $12.6 \pm 2.08$ & 00 \\
\hline
\end{tabular}




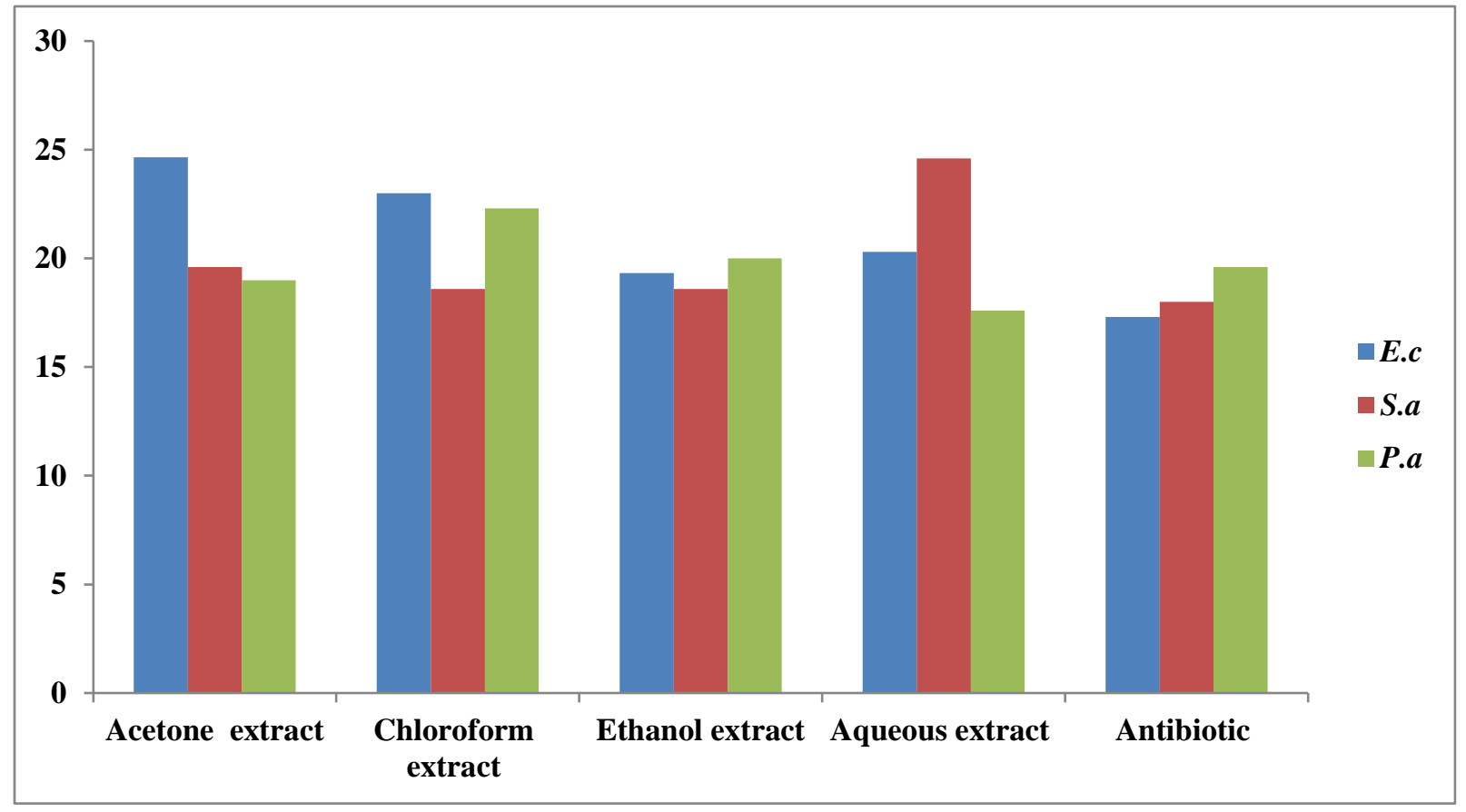

Figure 1. Zone of inhibition of leaf extracts of Cannabis sativa determined against bacteria by using Paper Disc Method

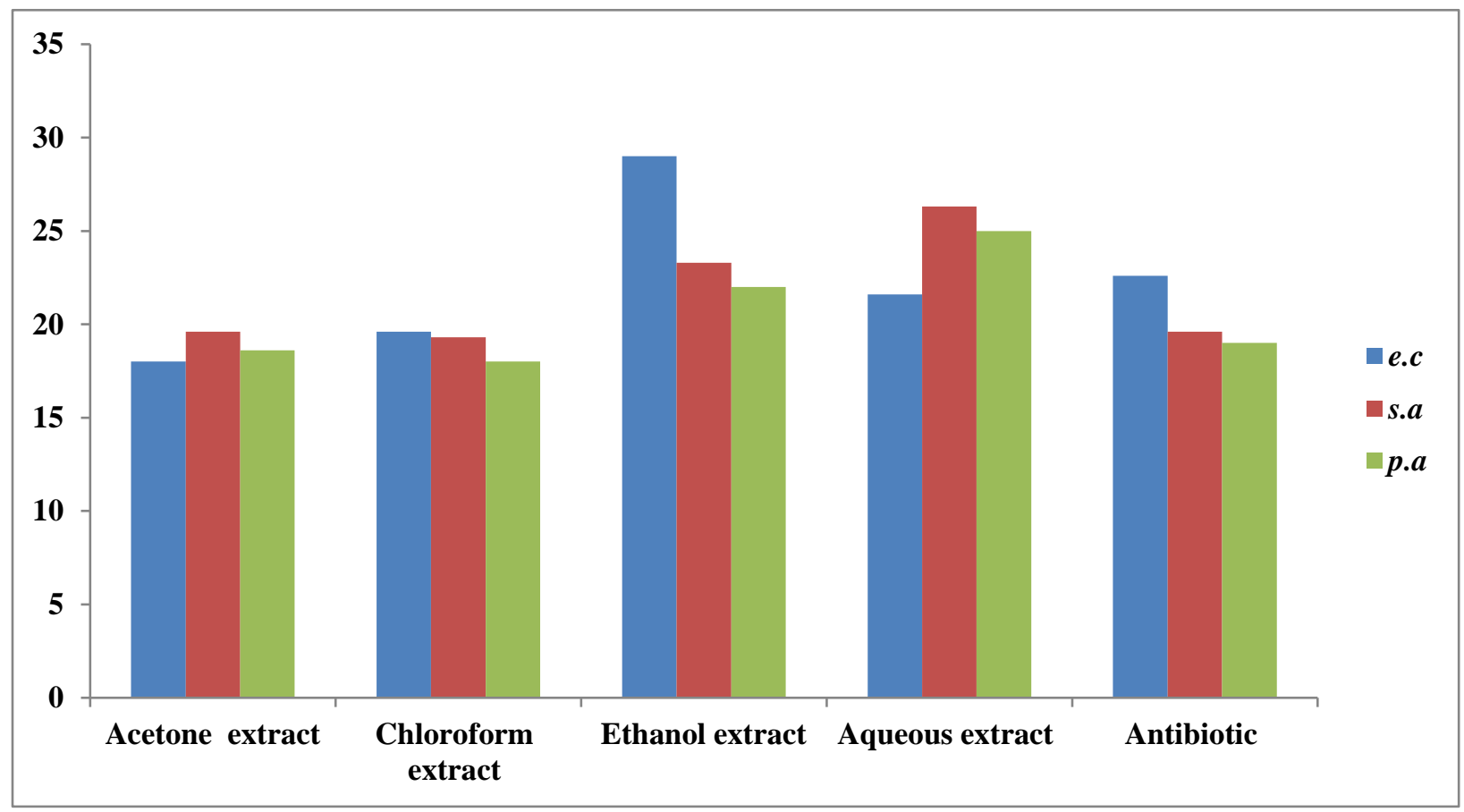

Figure 2. Zone of inhibition of leaf extracts of Cannabis sativa determined against bacteria by using Agar well diffusion Method 


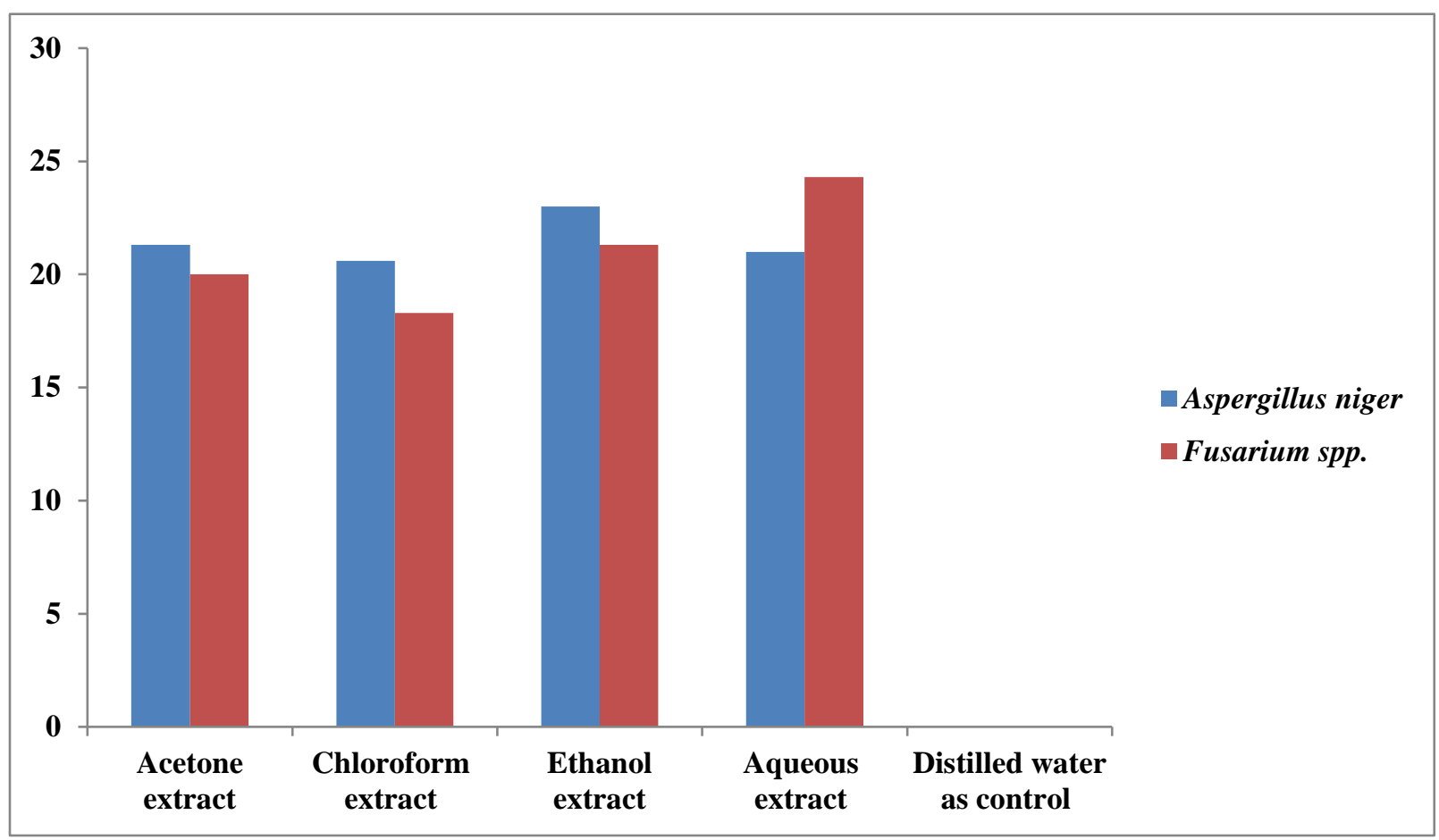

Figure 3. Zone of inhibition of leaf extracts of Cannabis sativa determined against fungi by using Paper Disc Method

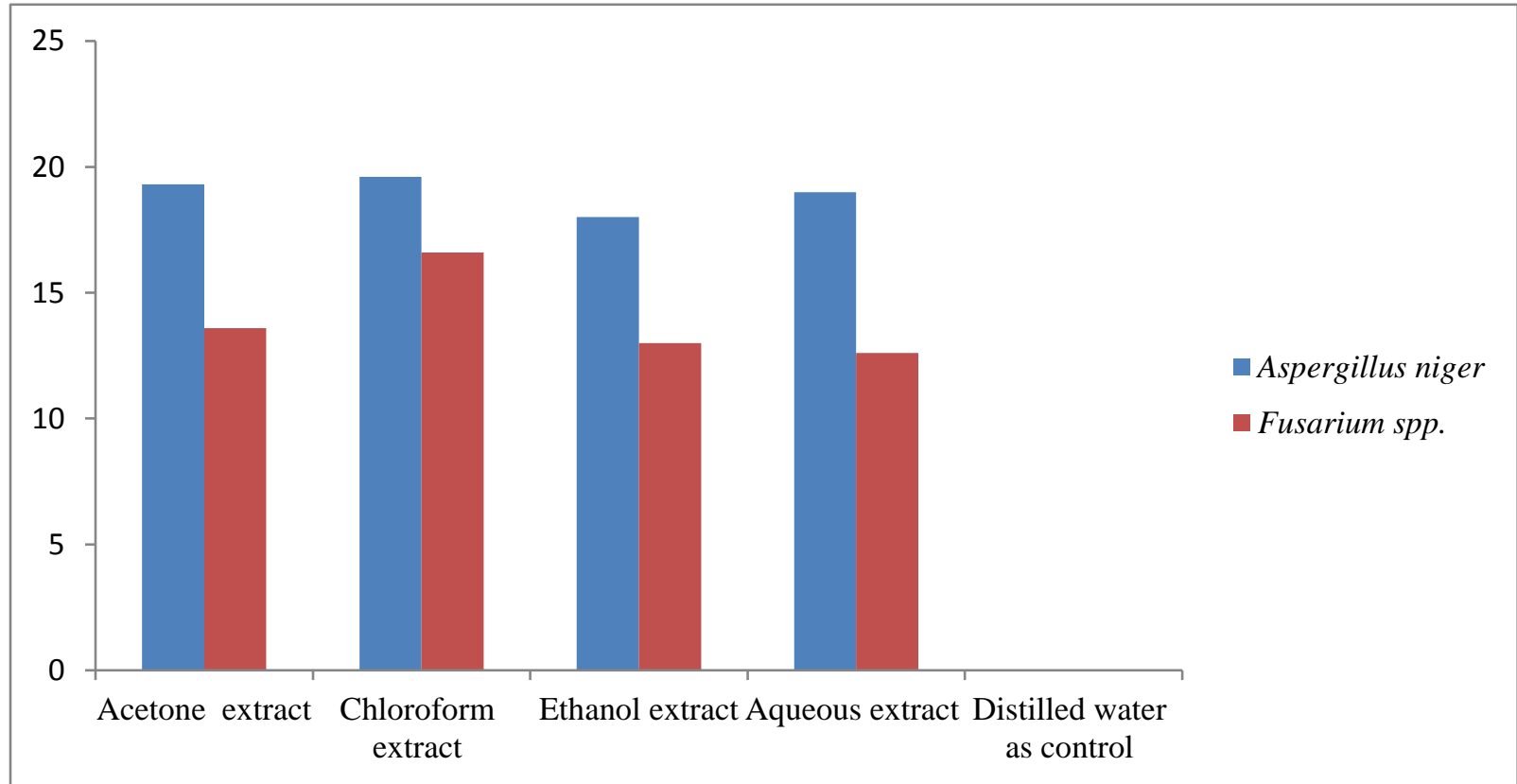

Figure 4. Zone of inhibition of leaf extracts of Cannabis sativa determined against fungi by using Agar well diffusion Method 


\section{List of ethnobotanical uses of cannabis sativa in study area according to the data collected by using questionnaire}

1. Used as a stimulant and tonic.

2. Used for stomach diseases, chest problems, whooping cough \& muscle contraction.

3. Seeds are occasionally eaten and much valued for feeding birds.

4. Leaves are used as green manure.

5. Seed oil is massaged on the affected part(s). The treatment is undertaken at bedtime once a day.

6. 1t is used to cure urogenital diseases.

7. It is also used as firewood.

8. Consumed in food as flavoring agent.

The plant extracts which included aqueous, chloroform, ethanolic and acetone extracts were studied for antimicrobial activity of Cannabis sativa. Our initial study displayed that all aqueous, chloroform, ethanol and acetone extracts of $C$. sativa were active against the bacteria including $S$. aureus, $P$. aeruginosa and $E$. coli fungal strains, Fusarium spp. and A.niger. The ethanol extracts of $C$. sativa portrayed significant activity of antimicrobial against selected microorganisms. For the action of these plant elements is not completely study, different types of solvent used for the, clear and effectiveness study of the plant. As compare to aqueous extracts maximum results exposed in organic extracts. Cowan explained that maximum compound for the antibiotic previously known in plant recorded as saturated organic or aromatic that can simply solubilized in organic solvents. The research also exposed that extract of aqueous and chloroform exposed moderated antimicrobial activity. The results similar with the research work of Esra et al. [3] that screened the activity of antimicrobial of $C$. sativa. Whole plant extracts of petroleum ether showed activity of the antibacterial 23$28 \mathrm{~mm}$ against both $B$. subtilis and $S$. aureus, maximum potential i.e., $16 \mathrm{~mm}$ against $E$. coli and inactive against $P$. aeruginosa and both fungi. The whole plant of the methanolic extract exposed $29 \mathrm{~mm}$ zone of inhibition against $B$. subtilis, low activity i.e., $12 \mathrm{~mm}$ against $S$. aureus and maximum activity i.e., 16-18 $\mathrm{mm}$ against both Gram negative organisms, inactive against $A$. niger and low activity $(13 \mathrm{~mm})$ against $C$. albicans. Naveed et al. [8] also worked on antibacterial activity of $C$. sativa and showed similar results that the leaf used definite acivity of antibacterial against $S$. aureus, $P$. aeruginosa, E.coli and Enterococcus faecalis $(24.1 \mathrm{~mm}),(10.3 \mathrm{~mm})$, $(22.2 \mathrm{~mm}), \quad(18.1 \mathrm{~mm})$ respectively and inactive against the two strains Klebsiella and Salmonella typhi.

\section{Conclusion}

In conclusion, of the current search Cannabis sativa comprises antimicrobial elements for the cure of numerous diseases that may be of excessive use for the progress of pharmaceutical industries as a therapy. Results exposed that extract of leaf showed notable activity of antimicrobial against all the experimental species. Some of the leaf extract of were Cannabis sativa acceptable with respect to the standard antibiotics and so can be used as a natural remedy for treatment of numerous fungal and bacterial infections without developing resistance among any fungal/bacterial species. The second aim of the study to enlist the ethno botanical uses of Cannabis sativa. It is reported that it is extensively used for various purposes as drug, to cure various diseases etc. Further research is needed on this plants to study other diseases which are not reported by local inhabitants and to utilize it in pharmacology, drugs production, phytochemistry and other fields of science.

\section{Authors' contributions}

Conceived and designed the experiments: $\mathrm{M}$ Anjum, Performed the experiments: S Azam \& J Khadim

Analyzed the data: P Rehman, Contributed materials/ analysis/ tools: J Khadim, Wrote the paper: ZE Arooj \& M Anjum. 


\section{References}

1. Schippmann U, Leaman JD \& Cunningham AB (2002). Impact of cultivation and gathering of medicinal plants on biodiversity: Global trends and issues, Inter-Departmental Working Group on Biological Diversity for Food and Agriculture, Rome.

2. WHO (2005). Global atlas of traditional, complementary and alternative medicine. World Health Organization, Geneva.

3. Esra MMA, Aisha ZIA, Salwa MEK \& Umelkheir MAG (2012). Antimicrobial Activity of Cannabis sativa L. Chinese Medicine 3: 61-64.

4. Mazher M, Anjum M, Mushtaq W, Noshad Q \& Malik NZ (2017).Antifungal assay of Solanum nigrum Linn. fruit, leaves and stems extracts in different solvents. Int J Biosci 10: 380-385.
5. Anjum M \& Hussain MA (2015). Antibacterial Screening of Different parts Datura alba Nees. Pharm Pharmaco Int J 2: 1-8.

6. Hassan A, Ajaib M, Anjum M, Siddiqui SZ \& Malik NZ (2016). Investigation of Antimicrobial and Antioxidant Activities of Cirsium wallichii DC. Biologia (PAK) 62: 297-304.

7. Omenka CA \& Osuoha JO (2000). Antimicrobial potency of Grapefruit seed extract on five selected pathogens. Niger $J$ Microbio 14: 39-42.

8. Naveed M, Khan TA, Ali I, Hassan A, Ali H, Din ZU, Hassan Z, Tabassum S, Majid A, Rehman MU (2014). In vitro antibacterial activity of Cannabis sativa leaf extracts to some selective pathogenic bacterial strains. Int J Biosci 4: 65-70. 